\title{
Editorial
}

\section{Sustainable Mineral Resource Management-Insights into the Case of Phosphorus}

\author{
Gerald Steiner ${ }^{1}$ (D) and Bernhard Geissler $1,2, *$ (D) \\ 1 Department of Knowledge and Communication Management, Danube University Krems, \\ Dr. Karl-Dorrek-Straße 30, 3500 Krems, Austria; gerald.steiner@donau-uni.ac.at \\ 2 Faculty of Geosciences, University of Resources TU Bergakademie Freiberg, Geoengineering and Mining, \\ Akademiestraße 6, 09599 Freiberg, Germany \\ * Correspondence: bernhard.geissler@donau-uni.ac.at
}

Received: 30 July 2018; Accepted: 31 July 2018; Published: 2 August 2018

\section{Introduction}

Although it is among the most abundant elements in Earth's crust (11th [1]) and water (13th [2]), phosphorus $(\mathrm{P})$ is commonly referred to as "life's bottleneck", as "life can multiply until all the phosphorus is gone, and then there is an inexorable halt which nothing can prevent ... " [3]. Historically, the first scientific knowledge about $\mathrm{P}$ and its impact on agriculture was acquired during the 19th century. Nevertheless, ancient farmers who lacked a deeper scientific understanding utilized macronutrients in manure and bones as fertilizers [4]. Ever since, phosphorus and its impact on agriculture, and therefore on food production, have gained interest and fostered demand. About half of today's crop yield can be directly attributed to the application of modern mineral fertilizers (consisting mostly of $\mathrm{P}$, nitrogen, and potash) $[5,6]$. This, in addition to its characteristics of being unsubstitutable, having a dissipative structure, and being finite in the form of concentrated deposits, makes phosphorus essential and unique.

Nowadays, $\mathrm{P}$ is almost exclusively produced by the mining of phosphate rock (PR) deposits of either sedimentary $(87 \%)$ or igneous $(13 \%)$ origin [7]. Currently, a total of 200 to 265 million metric tons [8] (depending on the data source), of marketable PR concentrate is mined and further processed to produce phosphorus fertilizer (83\%) or industrial P (17\%) [7]. Figure 1 provides a snapshot of the global situation, including production, consumption, imports, and exports, for the end use of phosphate nutrients in fertilizers in 1985 and 2015. It also shows China's dominant position (as part of eastern Asia) in terms of production and consumption, as well as increasing import dependency for regions such as Europe.

All the above make phosphorus and its primary source, phosphate rock, a unique mineral raw material embedded in a complex global supply chain. This complexity is well documented in the literature (e.g., $[9,10])$, but only a few authors aim toward clearing the smoke of complexity. Still, interest in the field is growing, as numerous special issues with varying foci have shown over the last few years (selected issues):

- December 2015, edited by Roland W. Scholz and Thomas Hirth: "Losses and Efficiencies in Phosphorus Management" in Resources, Conservation and Recycling (Vol. 105, Part B, Pages 211-368)

- January 2016, edited by Andrea E. Ulrich: "Special Issue on Sustainable Phosphorus Taking stock: Phosphorus supply from natural and anthropogenic pools in the 21st Century" in Science of The Total Environment (Vol. 542, Part B, Pages 1005-1168)

- April 2016, edited by Thomas Nesme and Paul J. A. Withers: "Integrating Approaches to Sustainable Phosphorus Management in Agroecosystems" in Nutrient Cycling in Agroecosystems (Vol. 104(3), Pages 259-427) 


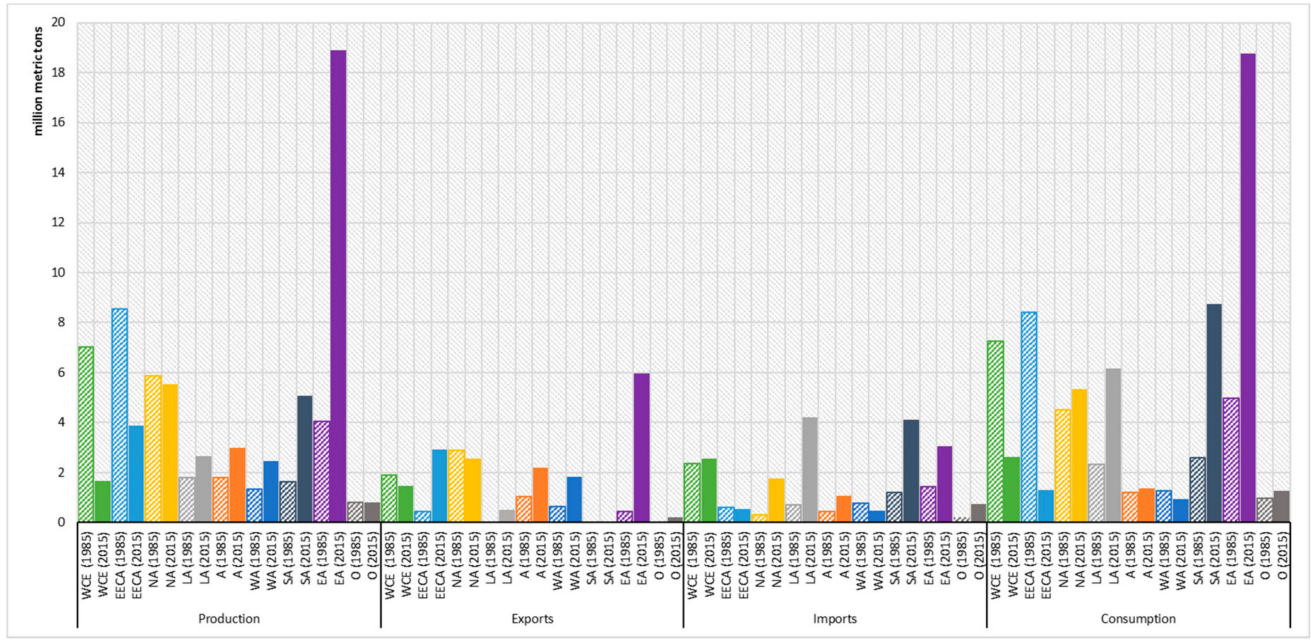

Figure 1. Production, exports, imports, and consumption of $\mathrm{P}_{2} \mathrm{O}_{5}$ in fertilizers for the years 1985 and 2015 (WCE: Western and Central Europe; EECA: Eastern Europe and Central Asia; NA: North America; LA: Latin America; A: Africa; WA: Western Asia; SA: Southern Asia; EA: Eastern Asia; O: Oceania) based on IFA (International Fertilizer Association) data (http:/ /ifadata.fertilizer.org/ucSearch.aspx).

Our aim is to contribute to a more holistic understanding of the underlying system dynamics along the supply chain for the benefit of scientific peers, industries, the public, and policy makers. The latter, especially, are the key to managing this limited resource in a more sustainable manner.

\subsection{Essentiality, Criticality, Scarcity, and the Peak Theory}

The question regarding available or potential substitutions represents the main distinction between criticality and essentiality. Scholz and Wellmer [11] use the example of energy; whereas energy is essential for society, the lack of primary resources such as uranium can be considered critical, but the basic function of producing energy, heat, motion, light, and power can be fulfilled by every energy source. Phosphorus, by contrast, represents one of the three macronutritional elements besides nitrogen $(\mathrm{N})$ and potassium $(\mathrm{K})$, and because it is not substitutable at all, P must be considered essential.

One major driver of the recent "popularity" of phosphorus is the ongoing discussion on scarcity. The literature reveals several types of scarcity [12-14], whereby this distinction is often neglected in discussions of P. The first is absolute scarcity, which equals the physical (un)availability (i.e., physical scarcity) of, in our case, a mineral. Second, relative scarcity deals with (un)availability under economic constraints (i.e., economic scarcity). Typically, economic scarcity occurs long before physical scarcity, as the extraction (in our case) of a mineral might still be possible from a technical stance, but the involved costs would exceed the willingness to pay for the mineral. Third and finally, structural scarcity represents a form of scarcity where the relationship between joint products (i.e., companion products or co-products) or by-products depends on (a) further (primary) product(s).

Most discussions about P or PR scarcity and its future availability have evolved around Hubbert's peak theory [15]. Originally used to model the oil market, the concept was used for phosphate rock, and soon the term "peak phosphorus" was coined, raising great awareness. Much has been written about its highly controversial application to the case of $P$ in recent years, for example [16-20], mostly around lack of availability of URR (ultimate recoverable resources) data and the comparability of oil and PR markets. However, this aspect is not within the scope of this special issue, and we point interested readers to the references mentioned above. 


\subsection{Economy, Circular Principles, and the Role of Innovation}

Merriam-Webster defines economy as (1) "the structure or conditions of economic life in a country, area, or period; also: an economic system", respectively; (2a) as the "thrifty and efficient use of material resources: frugality in expenditures; also: an instance or a means of economizing" [21]. In other words, an economy must be seen as a real-world system constraint by either geographic or temporal borders, which deals with resources based on the assumption of the rational choice of all agents [22]. However, circular economy (CE) is a concept that broadens the thoughts on purely economic rational choice in favor of sustainable development. The Ellen MacArthur Foundation defines it as follows:

"A circular economy is one that is restorative and regenerative by design and aims to keep products, components, and materials at their highest utility and value at all times, distinguishing between technical and biological cycles. This new economic model seeks to ultimately decouple global economic development from finite resource consumption. A circular economy addresses mounting resource-related challenges for business and economies, and could generate growth, create jobs, and reduce environmental impacts, including carbon emissions" [23].

Whereas we see a CE as a target state to aspire in a future economy, today's challenge must be to consider ways of operationalizing this goal. The application of circular principles, including circular production and use, to ultimately form circular supply chains is inevitable. Nevertheless, the transition from today's mostly linear supply chains requires a change in consumption behaviors, decision-making processes, and respective legislative frameworks. This involves firms and consumers on the microeconomic level, as well as policy makers on the macroeconomic level [22]. Innovation itself may be seen as a vehicle for change, whereby it is important to consider the multiplicity of innovation per se. Thus, rather than focusing solely on product and process innovation, we should also consider structural and social innovations of varying degrees (i.e., radical to incremental innovations) [24].

\section{The Content of This Special Issue}

Although in a perfect CE, primary resource consumption (i.e., mining) would be obsolete, there is a long way to go to reach that stage, and for now, mining remains an essential factor. [25]. However, if we break down the goal of attaining an overall circular economy into subgoals, such as a phosphorus circular economy, the complexity can be reduced. This will require an adjustment about how we perceive an economy. As stated above, common definitions foresee a system bound by either geographic or time-frame means. Thus, if we consider a phosphorus $\mathrm{CE}$, we define the value chain of $\mathrm{P}$ as the defining system boundary [22]. Below, Figure 2 is a first attempt to build on the linear Extended Phosphorus Supply Chain first introduced by Steiner et al. [26]. The agricultural phosphorus use cycle consists of the main phases of a P supply chain (black), some of the major losses involved in each phase (red), and several key challenges along the chain (green) where principles might be applied toward a circular economy of $\mathrm{P}$ and potential contributions made to an overall CE (e.g., the recovery of by-products such as uranium and rare earth elements or waste utilization). 


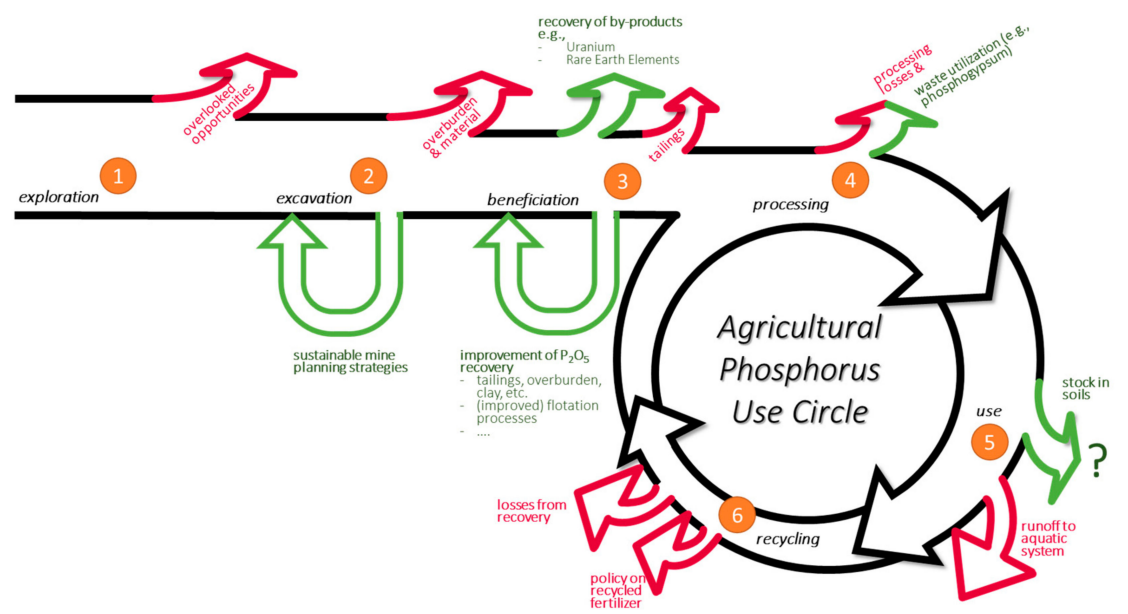

Figure 2. Circular principles for moving toward a circular phosphorus economy based on [22] categorizing [27-39].

Subsequently, Table 1 lists all contributions in the special issue. It is arranged in ascending order according to their main scope along the agricultural P use cycle. Each entry is complemented by core messages in a very brief summary of the main findings, as well as the keywords provided by the authors.

Table 1. Publications of the special issue categorized by their scope. P—phosphate; PR—phosphate rock.

\begin{tabular}{|c|c|c|}
\hline Wellmer and Scholz & What Is the Optimal and Sustainable Lifetime of a Mine? & 1 to 3 \\
\hline \multicolumn{3}{|c|}{$\begin{array}{l}\text { Content: The authors discuss how to maximize the use of phosphate rock from a sustainable as well as a purely economic } \\
\text { mine-planning perspective. Their approach evolves around the development of a discounting factor that includes future } \\
\text { sustainability aspects. } \\
\text { Keywords: sustainable mining; lifetime of a mine; break-even cut-off; sustainable cut-off; resource efficiency; cut-off grade }\end{array}$} \\
\hline Mew, Steiner, and Geissler & $\begin{array}{l}\text { hosphorus Supply Chain-Scientific, Technical, and Economic } \\
\text { Foundations: A Transdisciplinary Orientation }\end{array}$ & 2 to 5 \\
\hline \multicolumn{3}{|c|}{$\begin{array}{l}\text { Content: The manuscript aims to provide state-of-the-art knowledge as well as practical insights on issues along the } \\
\text { phosphorus supply chain. It is based on a long-term science-practice collaboration and an accompanying mutual learning } \\
\text { process, including geology, technology, economy, and policy perspectives. } \\
\text { Keywords: sustainable mineral resource management; phosphate rock; mineral raw materials; phosphate fertilizer; } \\
\text { pricing; raw material economics; phosphorus }\end{array}$} \\
\hline Khabarov and Obersteiner & $\begin{array}{c}\text { Modeling Global Trade in Phosphate Rock within a Partial } \\
\text { Equilibrium Framework }\end{array}$ & between 3 and 4 \\
\hline \multicolumn{3}{|c|}{$\begin{array}{l}\text { Content: Khabarov and Obersteiner are the first to apply a partial equilibrium approach to global PR market modeling } \\
\text { including a validation. The numerical solution through an LP (linear programming) approximation provides stable } \\
\text { accuracy and proves far superior to simple benchmark approaches. } \\
\text { Keywords: phosphate rock; international trade; partial equilibrium }\end{array}$} \\
\hline Hermann, Kraus, and Hermann & Phosphorus Processing_Potentials for Higher Efficiency & 4 \\
\hline \multicolumn{3}{|c|}{$\begin{array}{l}\text { Content: The paper focuses in particular on the processing of PR. Life cycle assessment as a potential evaluation tool for } \\
\text { current and potential industrial practices is discussed, as well as potentially conflicting goals between recovery efficiency } \\
\text { and factors such as low energy consumption. } \\
\text { Keywords: sustainable development goals; Paris Agreement; phosphorus; phosphogypsum; processing efficiency; } \\
\text { eutrophication; acidification; economic and regulatory framework; life cycle assessment (LCA) }\end{array}$} \\
\hline Mehr, Jedelhauser, and Binder & $\begin{array}{l}\text { Transition of the Swiss Phosphorus System toward a Circular } \\
\text { Economy_Part 1: Current State and Historical Developments }\end{array}$ & 4 and 5 \\
\hline \multicolumn{3}{|c|}{$\begin{array}{l}\text { Content: Mehr et al. conduct a material flow analysis of the Swiss P system for the year 2015. These results are compared } \\
\text { to 1989, and various differences such as P efficiency, import dependency, recycling, and losses are discussed in light of } \\
\text { established policy means. } \\
\text { Keywords: phosphorus; national scale; Switzerland; substance flow analysis; comparative analysis; policy; circular } \\
\text { economy; resource management }\end{array}$} \\
\hline
\end{tabular}


Table 1. Cont.

\begin{tabular}{ccc}
\hline Wellmer and Scholz & What Is the Optimal and Sustainable Lifetime of a Mine? & $\mathbf{1}$ to $\mathbf{3}$ \\
\hline Jedelhauser, Mehr, and Binder & $\begin{array}{c}\text { Transition of the Swiss Phosphorus System toward a Circular } \\
\text { Economy -Part 2: Socio-Technical Scenarios }\end{array}$ & $\mathbf{5}$ and $\mathbf{6}$ \\
\hline
\end{tabular}

Content: Part 2 builds on the contributions of Mehr, Jedelhauser, and Binder by developing three scenarios on landscape, regime, and niche level as potential pathways toward a sustainable $P$ future based on a multilevel perspective of transition theory. While scenarios one and two show the highest implications for primary and secondary P flows, the scenario including urine separation entails fundamental socio-technical shifts of the wastewater system, whereas sewage sludge recovery represents an incremental adaptation.

Keywords: phosphorus; Switzerland; scenario analysis; substance flow analysis; socio-technical transition; circular economy; human diets; recycling; sewage sludge; urine separation

Oster, Reyer, Ball, Fornara,
McKillen, Sørensen, Poulsen,
$\begin{aligned} & \text { Andersson, Ddiba, Rosemarin, } \\ & \text { Arata, Sckokai, Magowan, and } \\ & \text { Wimmers }\end{aligned}$

Content: Oster et al. consider the role of monogastric species (e.g., pigs and poultry) as sources of environmental P input. Their study addresses the aspects of feeding strategies, animal physiology, soil agroecosystems, and reuse and recycling as well as the farmer's economic performance and phosphorus policies with regard to a sustainable agricultural $\mathrm{P}$ circle. Keywords: agricultural cycle; bio-economic assessment; environmental phosphorus burden; farm animals; feeding strategies; monogastric species; phosphorus recycling; sustainable phosphorus governance
Römer and Steingrobe
Fertilizer Effect of Phosphorus Recycling Products
5 and 6

Content: The meta study addresses the fertilizer effect of a total of 32 different $P$ recycling products originating from various techniques including recovery from sewage sludge ashes, crystallization, precipitation, and struvite. The results show a clear differentiation in terms of effects: TSP $=$ struvite $>\mathrm{Mg}-\mathrm{P}=$ sinter-P $>\mathrm{Ca}-\mathrm{P}$, cupola-slag $>$ thermally treated sewage sludge ashes $>$ meat-and-bone meal ash $=$ Fe-P.

Keywords: phosphorus recycling; phosphorus fertilizer; sewage sludge ash; meat and bone meal ash; plant ash; calcium phosphates; magnesium phosphates; magnesium-ammonium-phosphate; struvite

$\begin{array}{ccc}\text { Strauch, Wenzel, Bischoff, } & \text { Commercial African Catfish (Clarias gariepinus) Recirculating } & \\ \text { Dellwig, Klein, Schüch, } & \text { Aquaculture Systems: Assessment of Element and Energy } & 5 \text { and } \mathbf{6} \\ \text { Wasenitz, and Palm } & \text { Pathways with Special Focus on the Phosphorus Cycle } & \end{array}$

Content: Strauch et al. focus on optimal reuse strategies for energy and nutrients from process water, fish carcasses, and sludge in an African catfish recirculating aquaculture system. The study shows that approximately $40 \%$ of the inputs (energy, total organic carbon, and nitrogen) are unaccounted for; the recovery of $P$ proved to be the best value. Process water and sewage prove to be nutrient rich. Although recorded concentration values are well below commercial fertilizers, they could still be used to a certain degree in aquaponics or in addition to fertilization.

Keywords: African catfish; recirculating aquaculture systems; mass balance; phosphorus; nutrients; pollutants; energy; solid wastes; aquaponics; circular economy

$\begin{array}{ccc}\begin{array}{l}\text { Withers, Doody, and } \\ \text { Sylvester-Bradley }\end{array} & \text { Achieving Sustainable Phosphorus Use in Food Systems through } \\ \text { Circularisation } & \mathbf{5} \text { and } \mathbf{6}\end{array}$

Content: The authors focus on the concept of minimization of $\mathrm{P}$ into the food system through reduced demand as well as the utilization of $\mathrm{P}$ from stores in the landscape. Both represent an essential element within $\mathrm{P}$ circulation and toward a circular P economy. Everything is considered under maintaining agricultural output.

Keywords: phosphorus; food system; circular economy; circularisation; minimisation; efficiency; resilience; sustainability

\begin{tabular}{ccc}
\hline Bongaerts & $\begin{array}{c}\text { A Model for the OptimalRrecovery of Multiple Substances from } \\
\text { Waste Water with a Focus on Phosphate }\end{array}$ & $\mathbf{6}$ \\
\hline
\end{tabular}

Content: Bongaerts uses optimal control modeling to describe the optimal simultaneous extraction strategy for multiple elements, including $\mathrm{P}$, from a wastewater treatment plant. The latter is referred to as a "liquid secondary mine", which turns wastewater, as an environmental problem, into a potentially valuable asset for operators.

Keywords: phosphate; wastewater treatment; optimal extraction; joint production; modeling; optimal control

\begin{tabular}{ccc}
\hline $\begin{array}{c}\text { de Boer, Romeo-Hall, Rooimans, } \\
\text { and Slootweg }\end{array}$ & $\begin{array}{c}\text { An Assessment of the Drivers and Barriers for the Deployment of } \\
\text { Urban Phosphorus Recovery Technologies: A Case Study of The } \\
\text { Netherlands }\end{array}$ & $\mathbf{6}$ \\
\hline
\end{tabular}

Content: The qualitative study uses semi-structured interviews to assess drivers and barriers of a phosphorus recovery transition. The Netherlands serves as a case study as it is seen as the frontrunner for P recovery technologies. Identified barriers include unclear differentiation between struvite and common fertilizer characteristics, the end-of-waste status of struvite, and reservations on potential economic returns from recovery. The low organic pollution of recovered P products as well as a potential reduction in maintenance costs are the most prominent drivers for recovery.

Keywords: phosphorus recovery; wastewater treatment plant; drivers and barriers; circular nutrient economy; socio-technical transitions

$\begin{array}{ccc}\text { Someus and Pugliese } & \text { Concentrated Phosphorus Recovery from Food Grade Animal } \\ \text { Bones } & 6\end{array}$

Content: Someus and Pugliese address an additional potential field for P recovery. Their study deals with P extraction from food-grade animal bone by-products using a specific zero emission autothermal carbonization system process (3R).

The animal bone char $(\mathrm{ABC})$ product demonstrates useful agronomic value and a high-quality innovative fertilizer.

Keywords: bio-phosphate; ABC animal-bone-char; 3R pyrolysis; phosphorus recovery; animal by-products; apatite

$$
{ }^{1} \text { British English in the title and keywords is intended by the respective authors. }
$$




\section{Conclusions and Outlook}

Great appreciation goes to all participating authors, the numerous anonymous reviewers, and the editorial team of Sustainability. Without each of them, this special issue would never have been possible. In our attempt to provide a clear and coherent storyline across the potential single contributions of this SI, we also organized an authors' workshop in November 2017, the 1st International Göttweig Mineral Resource Summit. This event was organized under the umbrella of the Transdisciplinarity Laboratory Sustainable Mineral Resources at Danube-University Krems in Austria (see www.donau-uni.ac.at/ smr-tdlab).

We are positive that each single contribution on its own contributes significantly to the field of phosphorus research. Thus, in coherent consideration of the form of this special issue, it should be seen as a state-of-the-art starting point for further research contributing to the journey toward sustainable management of this essential resource and, ultimately, to a circular economy of phosphorus.

Author Contributions: Both authors contributed equally to this editorial and in the process of guest editorship.

Acknowledgments: We thank Michael C. Mew for his valuable feedback and Elaine Ambrose for the thoughtful language editing of this paper.

Conflicts of Interest: The authors declare no conflict of interest.

\section{References}

1. Krauss, U.H.; Saam, H.G.; Schmidt, H.W. International Strategic Minerals Inventory Summary Report-Phosphate; U.S. Geological Survey: Reston, VA, USA, 1984.

2. Smil, V. Phosphorus in the environment: Natural flows and human interferences. Annu. Rev. Energy Environ. 2000, 25, 53-88. [CrossRef]

3. Asimov, I. Asimov on Chemistry; Doubleday \& Company: Garden City, NY, USA, 1974; ISBN 978-0-385-04100-3.

4. Scholz, R.W.; Roy, A.H.; Hellums, D.T. Sustainable phosphorus management: A transdisciplinary challenge. In Sustainable Phosphorus Management; Scholz, R.W., Roy, A.H., Brand, F.S., Hellums, D.T., Ulrich, A.E., Eds.; Springer: Dordrecht, The Netherlands, 2014; pp. 1-128. ISBN 978-94-007-7249-6.

5. Erisman, J.W.; Sutton, M.A.; Galloway, J.; Klimont, Z.; Winiwarter, W. How a century of ammonia synthesis changed the world. Nat. Geosci. 2008, 1, 636-639. [CrossRef]

6. Stewart, W.M.; Dibb, D.W.; Johnston, A.E.; Smyth, T.J. The contribution of commercial fertilizer nutrients to food production. Agron. J. 2005, 97, 1-6. [CrossRef]

7. Prud'homme, M. Trends in Global Phosphate Supply. In Proceedings of the 5th Sustainable Phosphate Summit, Kuming, China, 17 August 2016.

8. Geissler, B.; Steiner, G.; Mew, M.C. Clearing the fog on phosphate rock data-Uncertainties, fuzziness, and misunderstandings. Sci. Total Environ. 2018, 642, 250-263. [CrossRef] [PubMed]

9. De Ridder, M.; de Jong, S.; Polchar, J.; Lingemann, S. Risks and Opportunities in the Global Phosphate Rock Market-Robust Strategies in Times of Uncertainty; The Hague Centre for Strategic Studies: The Hague, The Netherlands, 2012.

10. Van Kauwenbergh, S.; Steward, M.; Mikkelsen, R. World Reserves of phosphate rock a dynamic and unfolding story. Better Crops 2013, 97, 18-20.

11. Scholz, R.W.; Wellmer, F.-W. Interactive comment on "Recent revisions of phosphate rock reserves and resources: Reassuring or misleading? An in-depth literature review of global estimates of phosphate rock reserves and resources" by J.D. Edixhoven, et al. Earth Syst. Dyn. Discuss 2013, 4, C574-C598.

12. Wolfensberger, M.; Lang, D.J.; Scholz, R.W. (Re-)Structuring the Field of Non-Energy Mineral Resource Scarcity Summary of the Workshop "Scarce Raw Materials"; NSSI: Davos, Switzerland, 2007.

13. Baumgärtner, S.; Becker, C.; Faber, M.; Manstetten, R. Relative and absolute scarcity of nature. Assessing the roles of economics and ecology for biodiversity conservation. Ecol. Econ. 2006, 59, 487-498. [CrossRef]

14. Mudd, G.M.; Weng, Z.; Jowitt, S.M.; Turnbull, I.D.; Graedel, T.E. Quantifying the recoverable resources of by-product metals: The case of cobalt. Ore Geol. Rev. 2013, 55, 87-98. [CrossRef]

15. Hubbert, M.K. Energy from fossil fuels. Science 1949, 109, 103-109. [CrossRef] [PubMed] 
16. Edixhoven, J.D.; Gupta, J.; Savenije, H.H.G. Recent revisions of phosphate rock reserves and resources: A critique. Earth Syst. Dyn. 2014, 5, 491-507. [CrossRef]

17. Edixhoven, J.D.; Gupta, J.; Savenije, H.H.G. Recent revisions of phosphate rock reserves and resources: Reassuring or misleading? An in-depth literature review of global estimates of phosphate rock reserves and resources. Earth Syst. Dyn. Discuss. 2013, 4, 1005-1034. [CrossRef]

18. Scholz, R.W.; Wellmer, F.-W. Comment on: "Recent revisions of phosphate rock reserves and resources: A critique" by Edixhoven et al. (2014)—Clarifying comments and thoughts on key conceptions, conclusions and interpretation to allow for sustainable action. Earth Syst. Dyn. 2016, 7, 1-15. [CrossRef]

19. Geissler, B.; Steiner, G. Interactive comment on “Comment on: 'Recentrevisions of phosphate rock reserves and resources: A critique' by Edixhovenet al. (2014)—Phosphate reserves and resources: What conceptions and data do stakeholders need for sustainable action?" by R.W. Scholz et al. (2015). Earth Syst. Dyn. Discuss 2015, 6, C56-C68.

20. Cordell, D.; White, S. Peak phosphorus: Clarifying the key issues of a vigorous debate about long-term phosphorus security. Sustainability 2011, 3, 2027-2049. [CrossRef]

21. Merriam-Webster Definition of Economy. Available online: https://www.merriam-webster.com/dictionary/ economy (accessed on 25 July 2018).

22. Geissler, B.; Hermann, L.; Mew, M.C.; Steiner, G. Striving toward a phosphorus circular economy: The role of phosphate rock mining. Minerals 2018. forthcoming.

23. Ellen MacArthur Foundation. Towards a Circular Economy: Business Rationale for an Accelerated Transition; Ellen MacArthur Foundation: Isle of Wight, UK, 2015; p. 20.

24. Geissler, B.; Mew, M.C.; Matschullat, J.; Steiner, G. The phosphate rock mining-innovation nexus. GAIA 2018, forthcoming.

25. Wellmer, F.-W. Nachhaltigkeit und Rohstoffgewinnung-ein Widerspruch? Sustainability and Exploitation of Raw Materials-A Contradiction? Erdöl Erdgas Kohle 2016, 132, 46-85.

26. Steiner, G.; Geissler, B.; Watson, I.; Mew, M.C. Efficiency developments in phosphate rock mining over the last three decades. Resour. Conserv. Recycl. 2015, 105, 235-245. [CrossRef]

27. Bongaerts, J.C. A model for the optimal recovery of multiple substances from waste water with a focus on phosphate. Sustainability 2018. forthcoming.

28. De Boer, M.A.; Romeo-Hall, A.; Rooimans, T.; Slootweg, J. An assessment of the drivers and barriers for the deployment of urban phosphorus recovery technologies: A case study of the Netherlands. Sustainability 2018, 10, 1790. [CrossRef]

29. Hermann, L.; Kraus, F.; Hermann, R. Phosphorus processing-Potentials for higher efficiency. Sustainability 2018, 10, 1482. [CrossRef]

30. Jedelhauser, M.; Mehr, J.; Binder, C. Transition of the Swiss phosphorus system towards a circular economy-Part 2: Socio-technical scenarios. Sustainability 2018, 10, 1980. [CrossRef]

31. Khabarov, N.; Obersteiner, M. Modeling global trade in phosphate rock within a partial equilibrium framework. Sustainability 2018, 10, 1550. [CrossRef]

32. Mehr, J.; Jedelhauser, M.; Binder, C. Transition of the Swiss phosphorus system towards a circular economy_Part 1: Current state and historical developments. Sustainability 2018, 10, 1479. [CrossRef]

33. Mew, M.C.; Steiner, G.; Geissler, B. Phosphorus supply chain-Scientific, technical, and economic foundations: A transdisciplinary orientation. Sustainability 2018, 10, 1087. [CrossRef]

34. Oster, M.; Reyer, H.; Ball, E.; Fornara, D.; McKillen, J.; Sørensen, K.; Poulsen, H.; Andersson, K.; Ddiba, D.; Rosemarin, A.; et al. Bridging gaps in the agricultural phosphorus cycle from an animal husbandry perspective-The case of pigs and poultry. Sustainability 2018, 10, 1825. [CrossRef]

35. Römer, W.; Steingrobe, B. Fertilizer effect of phosphorus recycling products. Sustainability 2018, 10, 1166. [CrossRef]

36. Someus, E.; Pugliese, M. Concentrated phosphorus recovery from food grade animal bones. Sustainability 2018, 10, 2349. [CrossRef]

37. Strauch, S.; Wenzel, L.; Bischoff, A.; Dellwig, O.; Klein, J.; Schüch, A.; Wasenitz, B.; Palm, H. Commercial African catfish (Clarias gariepinus) recirculating aquaculture systems: Assessment of element and energy pathways with special focus on the phosphorus cycle. Sustainability 2018, 10, 1805. [CrossRef] 
38. Wellmer, F.-W.; Scholz, R. What is the optimal and sustainable lifetime of a mine? Sustainability 2018, 10, 480. [CrossRef]

39. Withers, P.; Doody, D.; Sylvester-Bradley, R. Achieving sustainable phosphorus use in food systems through circularisation. Sustainability 2018, 10, 1804. [CrossRef] 